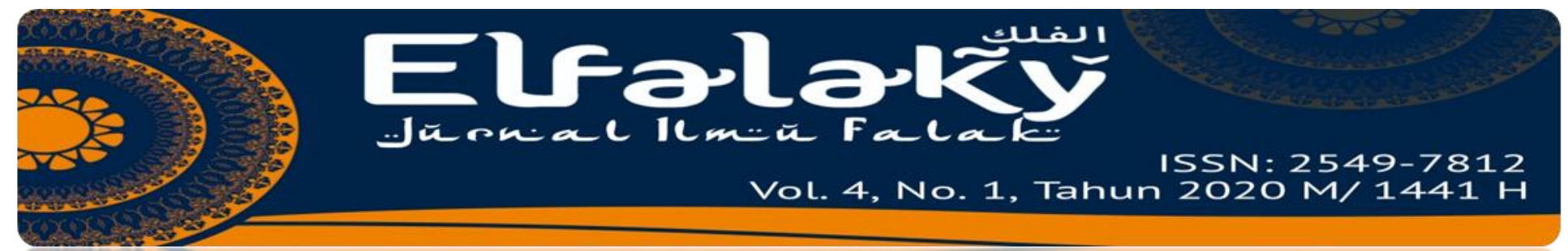

\title{
Gender dan Legitimasi Penentuan Awal Bulan Kamariah
}

\author{
Machzumy \\ Jurusan Astronomi Islam Fakultas Syariah \\ IAIN Lokseumawe, \\ machzumy17@gmail.com \\ Muh Rasywan Syarif \\ Ilmu Falak Fakultas Syariah dan Hukum \\ UIN Alauddin Makassar \\ rasywan.syarif@uin-alauddin.ac.id
}

\begin{abstract}
Rukyatul hilal activity is an annual agenda of the Ministry of Religion of the Republic of Indonesia to determine the entry of the early lunation month. As for the focus of the hilal rukyatul activity is the emergence of the new moon itself. So far, the determination of the beginning of the month is only done by male seaman, whereas women celestial experts also have the same opportunities and rights. But so far, the authors have not found any reports of hilal rukyat from women. This research uses library research method with a qualitative approach. The results of this study indicate that in the initial determination of the lunar month, female astronomers do not yet have the same rights and position as men.
\end{abstract}

Keyword: Determination of Kamariah, Gender

\section{PENDAHULUAN}

Diskursus perumusan penentuan awal bulan kamariah merupakan hal yang sudah lama menjadi problematika dan perhatian serius umat Islam. Hal ini terjadi karena banyaknya dimensi yang belum disepakati oleh para ahli falak. Implikasi lebih jauh adalah munculnya perpecahan baik itu antara penganut hisab atau rukyat. Ahli rukyat menganggap bahwa hisab itu tidak sesuai dengan sunnah karena memahami lafaz ru'yah sebagai sebuah perhitungan. Lain halnya dengan pandangan ahli hisab, rukyat itu bersifat tekstual karena mempertahankan cara lama dalam menentukan awal bulan. 1

1 Tim Majelis Tarjih dan Tajdid Pimpinan Muhammadiyah. (2009). Pedoman Hisab Muhammadiyah. Yogyakarta: Majelis Tarjih dan Tajdid Pimpinan Muhammadiyah, h. 75 


\section{ELFALAKY: JURNAL ILMU FALAK}

\section{Vol. 4. Nomor 1. Tahun $2020 \mathrm{M} / 1441 \mathrm{H}$}

Ahmad Izzuddin menyebutkan bahwa penentuan awal bulan Kamariah tak terlepas dari dua pendekatan, yakni pendekatan teoritis dan pendekatan observasi. Walaupun menggunakan pendekatan yang berbeda, semestinya akan bermuara pada hasil yang sama, karena baik itu yang dihisab ataupun yang diobservasi adalah mempunyai objek yang sama, yakni visibilitas hilal, maka seharusnya baik itu menggunakan hisab ataupun rukyat akan melahirkan hasil yang sama. Namun realitasnya, penggunaan pendekatan yang berbeda tersebut melahirkan hasil atau ketetapan yang berbeda. ${ }^{2}$

Tono Saksono menyatakan bahwa baik dengan pendekatan hisab maupun pendekatan rukyat, kedua-duanya masih mengandung kemungkinan untuk keliru. Hisab, kemungkinan keliru dapat disebabkan oleh perhitungan yang kurang tepat, ataupun data yang digunakan masih bersifat ' $u r f i$ ', dan hal teknis lainnya. Rukyat, walaupun mengandalkan observasi di lapangan, namun masih juga mungkin untuk keliru. Kekeliruan tersebut dapat disebabkan oleh perukyat itu sendiri yaitu psikologis perukyat, atau waktu rukyat yang tidak tepat, atau bahkan lokasi rukyat yang tidak ideal. ${ }^{4}$

Salah satu isu yang sering diperdebatan adalah kedudukan perempuan di dalam kegiatan rukyatul hilal, khususnya sebagai saksi/ perukyat hilal. Kegiatan observasi hilal merupakan kegiatan tahunan yang diadakan oleh Kementerian Agama Republik Indonesia dalam upaya menentukan kapan masuknya awal bulan kamariah. Penentuan ini sejatinya dilakukan oleh para ahli falak baik itu laki-laki maupun perempuan, karena seiring perkembangan zaman para ahli falak perempuan pun bermunculan. Namun sejauh ini penulis belum pernah menemukan kesaksian melihat hilal dari seorang ahli falak perempuan. Hal ini dapat terlihat dari tahun 2010 sampai

\footnotetext{
${ }^{2}$ Lihat Ahmad. Izzuddin, Fiqih Hisab Rukyat Menyatukan NU dan Muhammadiyah dalam Penentuan Awal Ramadhan, Idul Fitri dan Idul Adha. Jakarta: Erlangga, 2007.

${ }^{3}$ Urfi adalah perhitungan yang menggunakan data rata-rata peredaran Bulan mengelilingi Bumi. Tono Saksono, Mengkompromikan rukyat \& hisab. Jakarta: PT Amythas Publicita, 2007, h. 125 .

${ }^{4}$ Muhyiddin Khazin, 99 Tanya Jawab Masalah Hisab \& Rukyat. Yogyakarta: Ramadhan Press. 2009, h. 87.
} 


\section{ELFALAKY: JURNAL ILMU FALAK}

\section{Vol. 4. Nomor 1. Tahun $2020 \mathrm{M} / 1441 \mathrm{H}$}

2019 selalu saja kesaksian rukyat hilal diambil dari laki-laki dan disebutkan dalam berita acara rukyatul hilal Kementarian Agama Republik Indonesia. Padahal ada banyak ahli falak perempuan yang sangat menguasai dan mumpuni di dalam bidang ilmu falak, khususnya dalam penentuan awal bulan kamariah.

1. Tujuan penelitian

Penelitian ini bertujuan menelaah secara komprehensif terkait penentuan awal bulan kamariah dalam perspektif gender.

2. Metode penelitian

Penelitian ini merupakan penelitian kualitatif adalah penelitian yang menggunakan latar alamiah, dengan maksud menafsirkan fenomena yang terjadi dan dilakukan dengan jalan melibatkan berbagai metode yang ada dengan pendekatan library research dengan menelusuri berbagai dokumen terkait penentuan awal bulan kamariah dalam perspektif gender. ${ }^{5}$

\section{PEMBAHASAN}

Rukyatul hilal merupakan susunan kata majemuk yang berasal dari serapan bahasa Arab, yakni, ru'yat dan hilāl yang kemudian menjadi ru'yat al-hiläl. Munawir menukilkan bahwa kata rukyat berasal dari kata rā'a- yarā- ra'yān- ru'yatān, yang bermakna melihat, mengira, menyangka, menduga. ${ }^{6}$ Senada dengan pemaknaan tersebut, Khazin memaknai rukyat atau rukyah dengan makna melihat, yakni melihat atau mengamati benda langit. ${ }^{7}$ Kemudian Agustin (tt: 472) memahami rukyat sebagai kegiatan melihat bulan untuk menentukan mulai atau habisnya puasa Ramadan. Sedangkan dalam Kamus Besar Bahasa Indonesia rukyat adalah perihal melihat bulan tanggal satu untuk menentukan hari dengan permulaan dan penghabisan puasa

\footnotetext{
5 (Sugiyono, 2010: 8)

6 A. Warson Moenawwir, Al-Munawir, Kamus Arab-Indonesia, Surabaya: Pustaka Progresif, 2002, h. $494-495$.

${ }^{7}$ Muhyiddin Khazin, 99 Tanya Jawab Masalah Hisab \& Rukyat. Yogyakarta: Ramadhan Press. 2009, h. 69.
} 


\section{ELFALAKY: JURNAL ILMU FALAK}

\section{Vol. 4. Nomor 1. Tahun $2020 \mathrm{M} / 1441 \mathrm{H}$}

Ramadan. ${ }^{8}$ Rukyat juga diartikan sebagaimana beberapa pemaknaan di atas, namun lebih menitikberatkan kepada mekanismenya, sehingga rukyat dimaknai dengan melihat dengan mata. ${ }^{9}$

Dalam memaknai rukyat, kata $r \bar{a}^{\prime} a$ dapat dimaknai dengan tiga pengertian. Pertama, ra'a yang bermakna abshara atau rā'a bil fi'li artinya melihat dengan mata telanjang, yaitu apabila maf'ul bihī atau objeknya menunjukkan sesuatu yang terlihat. Kedua, rā'a yang bermakna alima/ adraka atau rā'a bil 'aqli artinya melihat dengan menggunakan akal pikiran (melihat dengan cara melakukan perhitungan) yaitu untuk objek yang berbentuk abstrak atau tidak dapat dilihat. Ketiga, $r \bar{a}$ 'a juga dapat bermakna dhanna atau rā'a bil qalbī artinya melihat dengan menggunakan hati (hanya berprasangka) yaitu untuk objeknya yang lebih dari satu.

Menurut Saksono yang dikutip dari al-Khalil bin Ahmad (seorang ahli linguistik Arab dari Oman, hilal didefinisikan dengan sinar Bulan pertama, ketika orang melihat dengan nyata bulan sabit pada sebuah awal bulan. ${ }^{10}$ Kata ini bisa saja berakar dari dua bentuk kalimat aktif yaitu muncul "halla", maupun pasif terlihat "uhilla" yang kedua-duanya melibatkan proses menyaksikan. Ahli linguistik Arab lainnya, Isfahani menjelaskan bahwa hilal berarti Bulan yang khusus kelihatan pada hari pertama dan kedua dalam sebuah bulan, setelah itu, maka dinamakan qamar saja. $^{11}$

Kemudian Thomas Djamaluddin mengatakan bahwasanya hilal adalah bulan sabit pertama yang teramati di ufuk barat sesaat setelah Matahari terbenam, tampak sebagai goresan garis cahaya yang tipis, dan jika menggunakan teleskop dengan pemroses citra bisa tampak sebagai garis cahaya tipis di tepi bulatan Bulan yang

\footnotetext{
${ }^{8}$ Departemen Pendidikan Nasional. Kamus Bahasa Indonesia. Jakarta: Pusat Bahasa, 2008, h. 932.

${ }^{9}$ Susiknan Azhari, Ensiklopedi Hisab Rukyat. Cet. Ke-2. Yogyakarta: Pustaka Pelajar, 2008, h. 183.

${ }^{10}$ Tono Saksono, Mengkompromikan rukyat \& hisab. Jakarta: PT Amythas Publicita, 2007, h. 83.

${ }^{11}$ Isfahani (2008: 229-231)
} 


\section{ELFALAKY: JURNAL ILMU FALAK}

\section{Vol. 4. Nomor 1. Tahun $2020 \mathrm{M} / 1441 \mathrm{H}$}

mengarah ke Matahari. ${ }^{12}$ Berdasarkan atas data-data rukyatul hilal jangka panjang, keberadaan hilal dibatasi oleh kriteria hisab tinggi hilal minimal sekian derajat bila jaraknya dari Matahari sekian derajat dan beda waktu terbenam Bulan-Matahari sekian menit serta fraksi iluminasi sekian persen.

Ru'yat al-hilāl dalam Kamus Besar Bahasa Indonesia dapat dipahami sebagai perihal melihat Bulan untuk menentukan mulai mmasuknya bulan Ramadan dan masuknya bulan Syawal. ${ }^{13}$ Kemudian Azhari mengatakan bahwa rukyat hilal adalah melihat atau mengamati hilal pada saat Matahari terbenam menjelang awal bulan Kamariah dengan mata atau teleskop, kegiatan ini dalam Astronomi dikenal dengan observasi. ${ }^{14}$ Sedangkan Khazin mengungkapkan bahwa rukyat hilal adalah usaha untuk melihat atau mengamati hilal di tempat terbuka dengan mata bugil atau peralatan sesaat Matahari terbenam menjelang bulan baru Kamariah. ${ }^{15}$ Sehingga rukyat hilal dapat dipahami sebagai suatu kegiatan melihat, menyangka, menduga, mengobservasi hilal di lokasi yang ideal sesaat Matahari terbenam menjelang bulan baru Kamariah, baik itu menggunakan alat bantu maupun dengan mata telanjang.

\section{Saksi}

Menurut Munawir Warson, saksi secara bahasa dengan Asy-syahadah (الثهادة) adalah bentuk isim masdar dari kata شهذ- يشه yang artinya menghadiri, melihat (dengan mata telanjang) dan mengetahui. ${ }^{16}$ Sedangkan menurut Wahbah Zuhaili syahada dapat bermakna informasi yang diberikan oleh seseorang yang jujur guna membuktikan kebenaran dengan lafal kesaksian di dalam majelis persidangan. ${ }^{17}$ Saksi adalah orang yang mengemukakan keterangan guna menetapkan hak atas orang lain.

${ }^{12}$ Djamaludin, Thomas. Menggagas Fiqh Astronomi (Telaah Hisab-Rukyat dan Pencarian Solusi Perbedaan Hari Raya. Bandung: Kaki Langit, 2013.

${ }^{13}$ Departemen Pendidikan Nasional. Kamus Bahasa Indonesia. Jakarta: Pusat Bahasa, 2008, h. 966.

${ }^{1414}$ Susiknan Azhari, Ensiklopedi Hisab Rukyat. Cet. Ke-2. Yogyakarta: Pustaka Pelajar, 2008, h. 183.

${ }^{15}$ Muhyiddin Khazin, 99 Tanya Jawab Masalah Hisab \& Rukyat. Yogyakarta: Ramadhan Press. 2009, h. 69.

${ }^{16}$ A. Warson Moenawwir, Al-Munawir, Kamus Arab-Indonesia, Surabaya: Pustaka Progresif, 2002, h. 746.

${ }^{17}$ Wahbah Zuhaili, Al-Fiqh al-Islamiy wa Adillatuhu, Damaskus: Dar al-Fikr, 1989, h. 556 


\section{ELFALAKY: JURNAL ILMU FALAK}

\section{Vol. 4. Nomor 1. Tahun $2020 \mathrm{M} / 1441 \mathrm{H}$}

Melihat kebiasaan masyarakat yang sangat mencatat segala tingkah muamalah dalam kehidupan sehari-hari, maka keberadaan saksi merupakan sebuah kebutuhan yang sangat mendasar, guna menjaga keharmonisan dalam kehidupan bermasyarakat dan kerukunan umat beragama. ${ }^{18}$

Adapun kesaksian secara syara sebagaimana dijelaskan oleh Wahbah Zuhaili dalam Fiqh al-Islam Wa Adillatuhu adalah sebuah pemberitahuan yang jujur untuk menetapkan, membuktikan, dan membenarkan suatu hak dengan menggunakan katakata asy-syahādah (bersaksi) di majelis persidangan. Berdasarkan beberapa pengertian di atas, maka dapat disimpulkan bahwa saksi adalah orang yang dapat memberikan keterangan terkait segala sesuatu baik itu dalam hal muamalah, ibadah dan perihal lainnya sebagaimana yang dilihat, didengar dan diketahui sendiri. Dalam hal rukyatul hilal, saksi adalah orang melihat atau menyaksikan secara langsung penampakan hilal dan itu bertanda sebagai masuknya awal bulan baru hijriah. ${ }^{19}$

Adapun terkait pandangan Imam mazhab tentang saksi, sebagaimana yang dikemukakan oleh Masykur bahwa Imam Syafi'i, imam Hanafi, dan imam Hambali sepakat bahwa perkawinan itu tidak sah tanpa adanya saksi. ${ }^{20}$ Begitu juga terkait dengan penentuan awal bulan kamariah, maka tidak dikatakan wajib berpuasa selama tidak ada saksi yang melihat hilal secara langsung yakni disaksikan oleh minimal dua orang lelaki yang adil. Akan tetapi, imam Hanafi memandang bahwa kesaksian itu cukup dengan hadirnya seorang laki-laki dan dua orang perempuan, tanpa disyaratkan harus adil.

Selanjutnya, ia juga menambahkan bahwa para ulama mazahab sepakat berpendapat bahwa kesaksian kaum wanita saja tanpa adanya laki-laki maka kesaksian tidak dapat diterima dan dinyatakan tidak sah, baik itu dalam pernikahan maupun dalam penentuan awal bulan Kamariah. Imam Syafi'i dan imam Hambali berpendapat bahwa perkawinan harus dengan dua saksi laki-laki, muslim dan adil.

${ }^{18}$ (Abdul Mujieb dkk: 1994, 306)

${ }^{19}$ Wahbah Zuhaili, 1989: (1989). Al-Fiqh al-Islamiy wa Adillatuhu. Damaskus: Dar al-Fikr, h. 556.

\footnotetext{
${ }^{20}$ Masykur: Masykur, Fiqih Lima Mazhab, Jakarta: Lentera, 2007, h. 313-314.
} 


\section{ELFALAKY: JURNAL ILMU FALAK}

\section{Vol. 4. Nomor 1. Tahun $2020 \mathrm{M} / 1441 \mathrm{H}$}

Sedangkan imam Malik berpendapat bahwa saksi laki-laki tidaklah wajib dalam sebuah akad, tetapi wajib untuk percampuran suami terhadap istrinya (dukhul). Kalau akad dilakukan tanpa saksi pun dipandang sah, tetapi bila suami bermaksud mencampuri istri, ia harus mendatangkan dua orang saksi. Apabila ia mencampuri istrinya tanpa ada saksi, maka akadnya harus dibatalkan secara paksa, dan pembatalannya ini sama dengan talak $b a^{\prime}$ in. Sementara itu Imamiyah berpendapat bahwa kesaksian dalam perkawinan hukumnya adalah istishab, atau hanya berupa sebuah anjuran dan bukan merupakan suatu kewajiban. ${ }^{21}$

a. Syarat saksi

Berdasarkan beberapa pandangan para ulama mazhab di atas, maka dapat dismpulkan ada beberapa syarat yang harus ada pada seorang saksi adalah: Islam, baligh, berakal, merdeka, adil, memiliki panca indera yang baik, minimal berjumlah 2 orang, dan berjenis kelamin laki-laki.

1) Islam

Syarat yang sangat utama dalam sebuah kesaksian adalah Bergama Islam, sehingga kesaksian orang kafir tidak bisa diterima, baik kafir dzimmi, maupun kafir harbi, baik ia memberikan kesaksian kepada orang Islam maupun kepada orang kafir. Imam Rafi'i beralasan dengan sabda Nabi saw:

Artinya: "Kesaksian pemeluk suatu agama terhadap pemeluk agama lain tidak bisa diterima, kecuali orang Islam, karena orangorang Islam itu adil terhadap diri mereka sendiri dan terhadap orang lain.”

Hadis di atas menggambarkan bahwa kesaksian itu adalah perkataan yang membawa dampak dan berlaku bagi orang lain, seperti kesaksian dalam melihat hilal. Kesaksian ini merupakan sebagai sebuah pegangan dalam menentukan awal dan akhirnya ibadah seseorang misalkan ibadah puasa. Sehingga kesaksian dapat dipahami sebagai sebuah penguasaan (kekuasaan menentukan berdasarkan hasil pengamatannya), sedangkan orang kafir tidak berhak menguasai seorang muslim,

\footnotetext{
${ }^{21}$ Masykur: Masykur, Fiqih Lima Mazhab, Jakarta: Lentera, 2007, h. 313-314.
} 


\section{ELFALAKY: JURNAL ILMU FALAK}

Vol. 4. Nomor 1. Tahun $2020 \mathrm{M} / 1441 \mathrm{H}$

apalagi menentukan kapan awal dan akhir suatu ibadah. Akan tetapi, imam Hanafi menyatakan bahwa apabila pernikahan antara seorang laki-laki muslim dan seorang wanita ahli kitab, maka saksinya boleh dua orang dari ahli kitab dan pernikahan itu dianggap tetap sah. ${ }^{22}$

2) Baligh

Terkait dengan baligh, Sayyid Sabiq terj. Abdurrhaman (2009, 465) berpendapat bahwa baligh sangat berkaitan erat dengan sifat adil. Dengan demikian tidak diterima kesaksian seseorang yang belum dewasa, seperti kesaksian seoarang anak kecil meskipun ia bersaksi terhadap anak kecil. Adapun orang gila juga digolongkan kepada belum baligh, karena akal dari orang gila terkadang seperti akal anak kecil sehingga pendapatnya tidak bisa dijadikan sebagai hujjah hukum. Adapun kesaksian anak-anak walaupun ia beranjak dewasa, maka kesaksiannya juga tidak dapat diterima.

3) Berakal

Imam Taqiyuddin berpendapat bahwa kesaksian orang gila tidak dapat diterima, karena perkataan anak kecil dan orang gila tidak bisa berpegaruh pada hak yang menyangkut dirinya sendiri ketika keduanya memberi pengakuan, apalagi untuk orang lain, tentu tidak bisa diterima. Imam Taqiyuddin beralasan dengan firman Allah dalam surat Al Baqarah ayat 282 yang artinya "Persaksikanlah dengan dua orang saksi laki-laki diantara kamu. Kalau tidak ada dua saksi laki-laki maka seorang saksi laki-laki dan dua saksi perempuan dari saksi-saksi yang kamu ridhai”. Sedangkan anak-anak tidak termasuk orang laki-laki dan anak-anak serta orang gila tidaklah termasuk orang yang diridai untuk memberi kesaksian. ${ }^{23}$

4) Merdeka

Djamaan Nur mengatakan bahwa imam Hanifi dan imam Syafi'i mensyaratkan orang yang menjadi saksi harus orang-orang yang merdeka, artinya bukan merupakan seorang hamba sahaya. Sedangkan Imam Hambali membolehkan

\footnotetext{
${ }^{22}$ Djamaan Nur, Fiqh Munakahat, Semarang: Toha Putra,1993, h. 63.

23 (Imam Taqiyuddin 1997: 433)
} 


\section{ELFALAKY: JURNAL ILMU FALAK}

\section{Vol. 4. Nomor 1. Tahun $2020 \mathrm{M} / 1441 \mathrm{H}$}

orang yang tidak merdeka menjadi saksi, karena di dalam Al-Quran maupun hadis tidak ada keterangan yang menolak budak untuk menjadi saksi, selama ia jujur serta amanah dalam kesaksiannya. ${ }^{24}$

\section{5) Adil}

Selanjutnya Djamaan Nur juga menyebutkan bahwa sifat yang juga harus terpenuhi pada saksi adalah sifat adil, dimana tidak pernah melakukan dosa besar dan tidak selalu berada dalam keadaan melakukan dosa kecil. ${ }^{25}$ Imam Hanafi mengatakan bahwa saksi dalam perkawinan tidak disyaratkan harus adil, jadis perkawinan yang disaksikan oleh dua fasiq hukumnya sah. Sedangkan Golongan Syafi'iyah berpendapat bahwa saksi itu harus orang yang adil sebagaimana disebutkan dalam hadis (tidak ada nikah kecuali dengan wali dan dua orang saksi yang adil).

6) Mendengar dan melihat serta paham terhadap apa yang disaksikan.

Seorang saksi harus mendengar dan memahami perihal yang dipersaksikan. Senada dengan yang disampaikan oleh M.Ali Hasan bahwa tidak mungkin orang dijadikan saksi adalah seseorang yang tidak mengerti terkait apa yang disaksikannya. ${ }^{26}$ Persyaratan ini dikemukakan oleh sebagian besar fukaha. Dapat melihat (tidak buta) merupakan salah satu syarat bagi saksi pernikahan, yang manapendapat ini hanya dikemukakan oleh ulama Mażhab Syafi' $i$, dengan argumen bahwa ungkapan dalam akad nikah tidak bisa dipastikan kecuali dengan melihat orang yang mengucapkannya. Sedangkan menurut Abu Ishaq jika kedua saksi dalam akad itu buta maka ada dua pendapat. Pertama, Akadnya tetap sah, karena sesungguhnya orang buta itu diperbolehkan menjadi saksi. Kedua, Akadnya tidak sah, karena sesungguhnya orang buta itu tidak mengetahui orang yang berakad. Adapun orang buta itu seperti halnya orang tuli yang tidak bisa mendengarkan lafaz orang yang berakat. ${ }^{27}$

\footnotetext{
${ }^{24}$ Djamaan Nur, Fiqh Munakahat, Semarang: Toha Putra. 1993, h. 63.

${ }^{25}$ Djamaan Nur, Fiqh Munakahat, Semarang: Toha Putra. 1993, h. 63.

${ }^{26}$ M. Ali Hasan, Perbandingan Madzhab Fiqh, Jakarta: PT.Raja Grafindo Persada, 2000, h. 49.

27 Abu Ishaq Ibrahim bin Ali bin Yusuf. t.t. Al-Muhazzab, Juz II, Beirut Libanon, Darul Kutub Ilmiyah, tt., h. 436
} 


\section{ELFALAKY: JURNAL ILMU FALAK}

\section{Vol. 4. Nomor 1. Tahun $2020 \mathrm{M} / 1441 \mathrm{H}$}

7) Jumlah saksi

Pendapat Ali Hasan terkait jumlah saksi, ia berpendapat sekurang-kurangnya saksi berjumlah dua orang sebagaimana telah disebutkan pada hadis yang diriwayatkan oleh Dara al-Quthny dan Ibnu Hibban. Selanjutnya ulama Hanafiyyah juga membenarkan dalam kasus seperti: seseorang menyuruh orang lain untuk menikahkan anaknya yang masih kecil (belum dewasa). Pada saat itu ada seorang laki-laki yang hadir bersama bapak anak wanita itu sebagai saksi. Pernikahan seperti ini dipandang sah, karena bapaknya ikut serta menyaksikan akad nikah itu. Berbeda sekiranya bapaknya tidak ikut menyaksikan, seperti tidak ada di tempat, nikah iu tidak sah karena saksi hanya seorang saja. Adapun dalam penentuan awal bulan kamariah, jumlah saksi juga minimal berjumlah dua orang, guna menghindari kesilapan seeorang dalam memberi kesaksian. ${ }^{28}$

8) laki-laki

Sebagaimana pendapat Sayyid Sabiq jumhur ulama sepakat bahwa laki-laki merupakan persyaratan saksi dalam akad nikah. ${ }^{29}$ Dua orang saksi harus laki-laki dan tidak sah akad nikah bila yang menjadi saksi wanita semua, atau seorang laki-laki dan dua orang wanita. Golongan Syafi'i dan Hambali mensyaratkan saksi harus laki-laki. Akan tetapi menurut ulama hanafiyah, laki-laki dua orang bukanlah suatu syarat yang harus dipenuhi, tapi cukup dengan seorang laki-laki dan dua perempuan.

\section{Kesaksian Perempuan}

a) Perempuan tanpa laki-laki

Ibnu Mundzir berpendapat sebagaimana yang dikutip oleh Ibnu Hajar terj. Abdullah, bahwa Para ulama sepakat menerima kesaksian wanita secara tersendiri (yakni tidak disertai laki-laki) yakni hanya dalam perkara yang tidak dapat diketahui

${ }^{28}$ M. Ali Hasan, Perbandingan Madzhab Fiqh, Jakarta: PT.Raja Grafindo Persada, 2000, h. 49.

${ }^{29}$ Sayyid Sabiq, Fikih Sunnah, Penerjemah Abdurrahim dan Masrukhin, Jakarta: Cakrawala Publishing.1980, h. 91. 


\section{ELFALAKY: JURNAL ILMU FALAK}

\section{Vol. 4. Nomor 1. Tahun $2020 \mathrm{M} / 1441 \mathrm{H}$}

oleh kaum laki-laki, seperti haid, kelahiran, tanda kehidupan dalam bayi yang baru lahir dan cacat fisik wanita. ${ }^{30}$

Para fukaha berselisih pendapat terkait jumlah saksi perempuan yang dapat dijadikan sebagai hujjah atau diterima kesaksiannya. Menurut imam Malik, maka cukup dua orang saja. Sedangkan menurut imam Syafi'i, kesaksian hanya dua orang wanita tidak cukup. Alasannya, Allah telah menjadikan seorang saksi lelaki itu sebanding dengan dua orang perempuan. Allah juga mensyaratkan saksi itu dua-dua. Menurut beberapa fukaha, kesaksian tersebut tidak boleh kurang dari tiga orang. ${ }^{31}$

Dalam masalah kelahiran dan cacat pada wanita, Imam Syafi'i berkata: "Proses kelahiran dan aib (cacat) pada wanita merupakan perkara yang diterima padanya kesaksian wanita tanpa disertai oleh laki-laki”. Senada dengan pendapat Ar-Rabi mengatakan bahwa, Kesaksian wanita yang tidak disertai oleh laki-laki dalam urusan wanita tidak dapat diterima apabila jumlahnya kurang dari empat orang yang adil. Ibnu Hajar mengatakan bahwa, para ulama berbeda pendapat dalam perkara yang umumnya tidak diketahui oleh laki-laki, maka menurut mayoritas ulama, disyaratkan empat orang saksi wanita. Sedangkan menurut Imam Malik dan Ibnu Abi Laila, cukup dua orang wanita. Lalu dari Asy-Sya "cbi dan Ats-Tsauri dikatakan, cukup seorang wanita. Pendapat ini pula yang dianut oleh ulama Madzhab Hanafi. $^{32}$

Kesaksian orang perempuan dan lelaki itu diperbolehkan dalam hal harta benda, nikah, rujuk, talak dan dalam segala sesuatu kecuali hudud dan qisas. Pendapat ini diperkuat oleh Ibnu Qayyim, dan katanya: Apabila pembuat syara memperbolehkan kesaksian wanita dalam dokumen-dokumen utang-piutang yang ditulis oleh kaum pria, sedang pada umumnya dokumen-dokumen itu ditulis di dalam majelis-majelis kaum pria; maka diperbolehkannya kaum wanita untuk menjadi saksi

${ }^{30}$ Ibnu Hajar Al Asqalani. (2005). Fathul Baari, Penerjemah Amiruddin, Jakarta: Pustaka Azzam, 2005, h. 97.

${ }^{31}$ Ibnu Rusyd, Bidayatul Mujtahid, Penerjemah Imam Ghazali Said dan Achmad Zaidun. Jakarta: Pustaka Amani, 2007, h. 692-693.

32 Ibnu Hajar Al Asqalani. (2005). Fathul Baari, Penerjemah Amiruddin, Jakarta: Pustaka Azzam, h. 97. 


\section{ELFALAKY: JURNAL ILMU FALAK}

\section{Vol. 4. Nomor 1. Tahun $2020 \mathrm{M} / 1441 \mathrm{H}$}

dalam urusan-urusan yang kebanyakan kaum wanita terlibat langsung di dalamnya jelas hal ini lebih diprioritaskan seperti dalam masalah wasiat dan rujuk. ${ }^{33}$

Selanjutnya Sayyid Sabiq juga berpendapat imam Al-Qurthubi memberikan alasan diterimanya kesaksian wanita dalam hal harta benda, katanya: Karena harta benda itu diperbanyak oleh Allah swt sebab-sebab konsolidasinya karena banyaknya cara untuk memperolehnya dan banyaknya kerusakan yang menimpanya serta perulangannya; oleh sebab itu Allah swt menjadikan konsolidasi harta benda itu terkadang melalui bencana, terkadang melalui kesaksian. Terkadang melalui tanggungan, dan terkadang pula melalui jaminan; dan ia masukkan ke dalam semuanya itu kaum wanita dan kaum pria.

Imam Syafi'i menyatakan bahwa kesaksian wanita tidak diterima kecuali pada dua tempat. Pertama, pada kasus dimana seorang laki-laki memiliki hak berupa harta pada laki-laki yang lain. Namun kesaksian mereka dalam kasus ini tidak diterima, kecuali ada bersama mereka seorang laki-laki yang turut memberikan kesaksian dan jumlah mereka minimal dua orang, karena Allah mempersyaratkan diterimanya kesaksian dua wanita apabila ada bersama mereka seorang laki-laki yang turut memberi kesaksian. Allah berfirman, "Jika tidak ada dua orang laki-laki (yang menjadi saksi), maka (boleh) seorang laki-laki dan dua orang perempuan". ${ }^{4}$

Kedua, pada kasus dimana laki-laki tidak boleh atau tidak dapat melihat; yaitu seperti melihat aurat kaum wanita. Sesungguhnya dalam masalah ini kesaksian mereka dapat diterima tanpa disertai oleh kesaksian laki-laki. Akan tetapi kesaksian mereka dalam masalah ini tidak diterima bila jumlahnya kurang dari empat orang. Hal ini diqiyaskan kepada hukum Allah sehubungan dengan mereka, dimana Allah menjadikan dua wanita menempati posisi satu orang laki-laki. Lalu Allah mempersyaratkan dalam suatu perkara agar hendaknya terdiri dari dua saksi laki-laki atau satu saksi laki-laki dan dua saksi wanita. Apabila wanita memberi kesaksian

\footnotetext{
${ }^{33}$ Sayyid Sabiq, Fikih Sunnah, Penerjemah Abdurrahim dan Masrukhin, Jakarta: Cakrawala Publishing.1980, h. 91.

${ }^{34}$ Sayyid Sabiq, Fikih Sunnah, Penerjemah Abdurrahim dan Masrukhin, Jakarta: Cakrawala Publishing.1980, h. 91.
} 


\section{ELFALAKY: JURNAL ILMU FALAK}

\section{Vol. 4. Nomor 1. Tahun $2020 \mathrm{M} / 1441 \mathrm{H}$}

secara tersendiri maka kedudukan dua saksi laki-laki dapat digantikan oleh empat wanita. Imam Syafi'i berpendapat bahwa kesaksian wanita pada kasus luka luka tidak disengaja dan kasus luka-luka disengaja namun tidak berlaku padanya hukum qishash dapat diterima bila disertai oleh saksi laki-laki. Adapun kesaksian wanita semata dalam kasus-kasus ini tidak dapat diterima. ${ }^{35}$

\section{Diskriminasi Perempuan dalam Kesaksian}

Manusia sebagai makhluk social memiliki dua pokok tanggung jawab dalam membangun masyarakat majemuk. Pertama, menjunjung tinggi HAM. Kedua menjunjung tinggi KAM (kewajiban asasi manusia). Ham dan KAM tidak dapat direalisaiskan secara terpisah. Keduanya sejajar dan terealisasikan secara beriringan. HAM lebih terfokus kepada terwujudnya hak individu. Sedangkan KAM menjamin guna hak orang lain terlaksana dengan sepenuhnya. Jika hal ini tidak diperhatikan maka akan menimbulkan kesenjagan social bahkan diskriminasi (Dewi Ratnawati, dkk, 2019: Jurnal Harkat).

Diskriminasi dapat dimaknai sebagai sebuah perlakuan berbeda terhadap individu yang ditentukan berdasarkan gender, ras, agama, umur, atau karakteristik yang lain. Diskriminasi sangat diidentik dengan perlakuan berbeda, akibatnya timbul masalah ketidakadilan dalam memperlakukan seorang individu. Mosse menyatakan bahwa perempuan yang berkerja di luar rumah sangat minim. ${ }^{36}$

Selanjutnya Robins $(2008,79)$ menjelaskan salah satu bentuk diskriminasi dalam pemberian imbalan kerja, wanita biasanya dibayar (upah) lebih sedikit daripada pria dalam pekerjaan-pekerjaan yang sebanding dan mempunyai harapanharapan imbalan kerja yang lebih rendah daripada pria untuk pekerjaan yang sama. Selanjutnya Fakih mengemukakan secara rinci manifestasi ketidakadilan

\footnotetext{
${ }^{35}$ Sayyid Sabiq, Fikih Sunnah, Penerjemah Abdurrahim dan Masrukhin, Jakarta: Cakrawala Publishing.1980, h. 91.

${ }^{36}$ Mosse, Julia Cleves, Gender dan Pembangunan, Yogyakarta: Pustaka Pelajar, 2007, h. 34.
} 


\section{ELFALAKY: JURNAL ILMU FALAK}

\section{Vol. 4. Nomor 1. Tahun $2020 \mathrm{M} / 1441 \mathrm{H}$}

gender, yaitu: marjinalisasi (peminggiran), subordinasi (penomorduaan), stereotipe, kekerasan (violence), dan beban kerja berlebihan. ${ }^{37}$

Penelitian Armstrong dan Vincent (1988) mengemukakan bahwa profesi harus didasari oleh profesional dan keahlian, profesional membutuhkan extensive training misal job training dan pengalaman. Sedangkan keahlian atau special knowledge dibutuhkan pengakuan dalam bentuk sertifikasi. Seorang yang profesional di dalam melakukan suatu profesi biasanya akan memiliki motivasi yang tinggi. Seorang auditor bisa dikatakan profesional apabila telah memenuhi dan mematuhi standar-standar kode etik yang telah ditetapkan oleh IAI, antara lain:

1. Prinsip-prinsip yang ditetapkan oleh IAI yaitu standar ideal dari perilaku etis yang telah ditetapkan oleh IAI seperti dalam terminologi filosofi.

2. Peraturan perilaku seperti standar minimum perilaku etis yang ditetapkan sebagai peraturan khusus yang merupakan suatu keharusan.

3. Inteprestasi peraturan perilaku tidak merupakan keharusan, tetapi para praktisi harus memahaminya.

4. Ketetapan etika seperti seorang akuntan publik wajib untuk harus tetap memegang teguh prinsip kebebasan dalam menjalankan proses auditnya, walaupun auditor dibayar oleh kliennya. ${ }^{38}$

Profesionalisme menurut Hall (1968) dalam Sumardi (2001) dijabarkan menjadi lima dimensi, yaitu (1) komunitas afiliasi (community affiliation) (2) kebutuhan autonomi (autonomy demand) (3) keyakinan terhadap peraturan sendiri (self regulation) (4) dedikasi terhadap profesi (dedication) (5) kewajiban sosial (sosial obligation). Minimnya peran perempuan dalam menentukan awal bulan Kamariah merupakan suatu bentuk diskriminasi. Sejatinya yang berhak memberikan kesaksian dalam penentuan awal bulan kamariah adalah seoarang ahli falak yang

\footnotetext{
2008 , h. 41.

${ }^{37}$ Fakih, Mansour, Analisis Gender dan Transformasi Sosial, Yogyakarta: Pustaka Pelajar,

38 Ikhsan, "Profesionalisme Auditor pada Kantor Akuntan Publik Dilihat dari Perbedaan Gender, Kantor Akuntan Publik dan Hirarki Jabatannya", dalam Jurnal Bisnis dan Akuntansi. Vol. 9, No. 2, 2007, h. 341.
} 


\section{ELFALAKY: JURNAL ILMU FALAK}

\section{Vol. 4. Nomor 1. Tahun $2020 \mathrm{M} / 1441 \mathrm{H}$}

memiliki jiwa propesionalitas, baik itu laki-laki maupun perempuan. Apabila perempuan tidak dapat dijadikan sebagai saksi dalam rukyatul hilal, maka sejatinya sudah terjadi diskriminasi terhadap perempuan untuk mengemukakan pendapat.

\section{KESIMPULAN}

Adapun hasil penelitian ini menunjukkan bahwa dalam penentuan awal bulan Kamariah, para ahli falak perempuan belum memiliki hak dan kedudukan yang sama dengan perukyat laki-laki. Hal ini merupakan sebuah diskriminasi terhadap perempuan. Karena sejatinya perempuan memiliki hak yang sama seperti lelaki dalam memberikan kesaksian terhadap penampakan hilal, walaupun dengan perbandingan 2 : 1 dengan laki-laki. Akan tetapi sejauh ini belum ada kesaksian hilal yang diterima dari seorang pengamat perempuan, padahal tidak jarang juga para ahli falak dari kalangan perempuan.

\section{DAFTAR PUSTAKA}

A. Warson Moenawwir. (2002). Al-Munawir, Kamus Arab-Indonesia. Surabaya: Pustaka Progresif.

Abi Ishaq Ibrahim bin Ali bin Yusuf. t.t. Al-Muhazzab, Juz II, Beirut Libanon, Darul Kutub Ilmiyah.

Djamaan Nur. (1993). Fiqh Munakahat, Semarang: Toha Putra.

Departemen Pendidikan Nasional. Kamus Bahasa Indonesia. Jakarta: Pusat Bahasa, 2008.

Dewi Ratnawati. dkk. (2019). Kesetaraan Gender tentang Pendidikan Lakilai dan Perempuan. Jurnal Harkat: Media Komunikasi Gender, 15 (1).

Fakih, Mansour. (2008). Analisis Gender dan Transformasi Sosial. Yogyakarta: Pustaka Pelajar. 


\section{ELFALAKY: JURNAL ILMU FALAK}

\section{Vol. 4. Nomor 1. Tahun $2020 \mathrm{M} / 1441 \mathrm{H}$}

Ibnu Hajar Al Asqalani. (2005). Fathul Baari, Penerjemah Amiruddin, Jakarta: Pustaka Azzam.

Ibnu Rusyd. (2007). Bidayatul Mujtahid, Penerjemah Imam Ghazali Said dan Achmad Zaidun. Jakarta: Pustaka Amani.

Ikhsan, Arfan. 2008. Metodologi Penelitian Akuntansi Keperilakuan. Edisi Pertama. Yogyakarta: Graha Ilmu.

----osember. (2007). "Profesionalisme Auditor pada Kantor Akuntan Publik Dilihat dari Perbedaan Gender, Kantor Akuntan Publik dan Hirarki Jabatannya", dalam Jurnal Bisnis dan Akuntansi. Vol. 9, No. 2, 199-222.

Imam Syafii. (2008). Ringkasan Kitab Al Umm, Penerjemah Amiruddin, Jakarta: Pustaka Azam

Izzuddin, Ahmad. (2007). Fiqih Hisab Rukyat Menyatukan NU dan Muhammadiyah dalam Penentuan Awal Ramadhan, Idul Fitri dan Idul Adha. Jakarta: Erlangga.

Khazin, Muhyiddin. (2009). 99 Tanya Jawab Masalah Hisab \& Rukyat. Yogyakarta: Ramadhan Press.

M. Abdul Mujieb. (1994). Kamus Istilah Fiqih, Jakarta: PT. Pustaka Firdaus

M. Ali Hasan. (2000). Perbandingan Madzhab Fiqh, Jakarta: PT.Raja Grafindo Persada.

Macdonald, Mandy dan Sprenger, Ellen. 1997. Gender dan Perubahan Organisasi. Yogyakarta: Insist Press.

Masykur. (2007). Fiqih Lima Mazhab, Jakarta: Lentera.

Mosse, Julia Cleves. 2007. Gender dan Pembangunan. Yogyakarta: Pustaka Pelajar.

Robins, Stephen P. dan Judge, Timothy A. 2008. Perilaku Organisasi edisi Kedua belas. Jakarta: Salemba Empat.

Saksono, Tono. (2007). Mengkompromikan rukyat \& hisab. (Jakarta: PT Amythas Publicita). 


\section{ELFALAKY: JURNAL ILMU FALAK}

Vol. 4. Nomor 1. Tahun $2020 \mathrm{M} / 1441 \mathrm{H}$

Sayyid Sabiq. (2009). Fikih Sunnah, Penerjemah Abdurrahim dan Masrukhin. Jakarta: Cakrawala Publishing.

Sumardi. 2001. Pengaruh Pengalaman terhadap Profesionalisme serta Pengaruh Profesionalisme terhadap Kinerja dan kepuasan Kerja (Studi Empiris: Auditor BPKP), Tesis Magister Sains Akuntansi, Universitas Diponegoro Semarang.

Susiknan Azhari, Ensiklopedi Hisab Rukyat. Cet. Ke-2. Yogyakarta: Pustaka Pelajar, 2008.

Syarif, Muh Rasywan. "Diskursus Perkembangan Formulasi Kalender Hijriah." ELFALAKY 2.1 (2018).

Syarif, Muh. "Reformasi Kalender Hijriyah: Maslahah atau Mudharat?." (2015): 9-15.

Thomas Djamaludin, Menggagas Fiqh Astronomi (Telaah Hisab-Rukyat dan Pencarian Solusi Perbedaan Hari Raya. Bandung: Kaki Langit, 2005

Tim Majelis Tarjih dan Tajdid Pimpinan Muhammadiyah. (2009). Pedoman Hisab Muhammadiyah. Yogyakarta: Majelis Tarjih dan Tajdid Pimpinan Muhammadiyah.

Wahbah Az-Zuhaili. (2011). Fiqih Islam Wa Adillatuhu. Jakarta: Gema Insani.

(1989). Al-Fiqh al-Islamiy wa Adillatuhu. Damaskus: Dar al-Fikr. 